\title{
PLASMA CATHEPSIN S IS ASSOCIATED WITH HIGH-DENSITY LIPOPROTEIN CHOLESTEROL AND BILIRUBIN IN PATIENTS WITH ABDOMINAL AORTIC ANEURYSMS
}

\section{POVEZANOSTI PLAZMATSKOG KATEPSINA S SA HOLESTEROLOM LIPOPROTEINA VISOKE GUSTINE I BILIRUBINOM KOD PACIJENATA SA ANEURIZMOM ABDOMINALNE AORTE}

\author{
Bosa Mirjanic-Azaric ${ }^{1,2}$, Novak Vasic 3 , Darko Cerne ${ }^{4}$, Janko Kos ${ }^{4,5}$, Natasa Bogavac-Stanojevic 6 \\ ${ }^{1}$ Institute of Laboratory Diagnostic, University Clinical Centre of the Republic of Srpska, \\ Banja Luka, Bosnia and Herzegovina \\ ${ }^{2}$ Medical Faculty, University of Banja Luka, Banja Luka, Bosnia and Herzegovina \\ ${ }^{3}$ Vascular Surgery Clinic, University Clinical Centre of the Republic of Srpska, Banja Luka, \\ Bosnia and Herzegovina \\ ${ }^{4}$ Faculty of Pharmacy, University of Ljubljana, Ljubljana, Slovenia \\ ${ }^{5}$ Department of Biochemistry and Molecular Biology, Jožef Stefan Institute, Ljubljana, Slovenia \\ ${ }^{6}$ Department of Medical Biochemistry, Faculty of Pharmacy, University of Belgrade, Belgrade, Serbia
}

\section{Summary}

Background: Cathepsin S (CTSS) is a cysteine protease involved in atherogenesis. We compared the plasma CTSS as well as other biomarkers of atherosclerosis in patients with abdominal aortic aneurysms (AAA) and aortoiliac occlusive disease (AOD), aiming to identify the underlying pathogenic mechanisms of the disease development. Also, we hypothesised that the level of plasma CTSS simultaneously increases with a decrease of plasma high-density lipoprotein cholesterol (HDL-C) values.

Methods: 33 patients with AAA and 34 patients with AOD were included in this study.

Results: There was no difference in the level of plasma CTSS between the two analysed groups $(p=0.833)$. In the patients with AAA, the plasma CTSS was correlated with HDL-C $(r=-0.377, p=0.034)$ and total bilirubin $(r=$ $0.500, p=0.003$ ) while, unexpectedly, it was not correlated with cystatin $C$ (Cys $C)(r=0.083, p=0.652)$. In the patients with $A O D$, the plasma CTSS correlated with triglycerides

\section{Kratak sadržaj}

Uvod: Katepsin S (CTSS) je cisteinska proteaza uključena u aterogenezu. Uporedili smo plazmatski CTSS kao i druge biomarkere ateroskleroze kod pacijenata sa aneurizmom abdominalne aorte (AAA) i aorto ilijačnom okluzivnom bolešću (AOD) sa ciljem da se identifikuju osnovni patogeni mehanizmi razvoja bolesti. Takođe, pretpostavili smo da se nivo plazmatskog CTSS istovremeno povećava sa smanjenjem vrednosti holesterola plazmatskih lipoproteina visoke gustine (HDL-C).

Metode: Ova studija je obuhvatila 33 pacijenta sa AAA i 34 pacijenta sa AOD.

Rezultati: Nije bilo razlike u nivou plazmatskog CTSS između dve analizirane grupe ( $p=0,833)$. Kod pacijenata sa AAA, plazmatski CTSS je bio u korelaciji sa HDL-C ( $r=-0,377$, $p=0,034)$ i ukupnim bilirubinom $(r=-0,500, p=0,003)$, dok, neočekivano, nije bio u korelaciji sa cistatinom C (Cys C) $(r=0,083, p=0,652)$. Kod pacijenata sa AOD, plazmatski CTSS je bio u korelaciji sa trigliceridima ( $r=0,597$,

Address for correspondence:

Dr Bosa Mirjanić-Azarić

Institute of Laboratory Diagnostic,

University Clinical Centre of the Republic of Srpska, 12

Babies Street, 78000 Banja Luka,

Bosnia and Herzegovina

e-mail: bodamirjanic@blic.net 
( $r=0.597, p<0.001$ ), only. When the patients were divided according to HDL-C (with HDL-C $\leq 0.90$ and HDLC $>0.90 \mathrm{mmol} / \mathrm{L})$, the plasma CTSS values differed among these groups (31.27 vs.25.61 $\mu \mathrm{g} / \mathrm{L}$, respectively, $\mathrm{p}<0.001)$.

Conclusions: These results provide the first evidence that CTSS negatively correlated with HDL-C and bilirubin in patients with AAA. It is possible that differences in the association of the CTSS and other markers of atherosclerosis can determine whether atherosclerotic aorta will develop dilatation or stenosis.

Keywords: abdominal aortic aneurysm, cathepsin S, cystatin C, HDL-C

\section{Introduction}

Studies demonstrate that abdominal aortic aneurysms (AAA) and aortoiliac occlusive disease (AOD) are related to underlying atherosclerotic disease $(1,2)$. However, consequences of these diseases are different. AAA results in abdominal aorta dilatation while AOD results in occlusion of main arteries in the pelvis.

A recent study by Peshkova et al. (3) shows that there are several theories regarding the AAA etiology. One is that atherosclerosis-driven changes in the aortic wall underlie AAA pathology, and the inflammatory mechanisms promoting atherosclerosis contribute to AAA. The second possibility is that different risk factors promote AAA and atherosclerosis separately, and they thus develop independently without greatly influencing one another. The third possibility is that the same risk factors promote both AAA and atherosclerosis via similar mechanisms, although additional factors are required for AAA induction.

Cathepsin S (EC 3.4.22.27) (CTSS) is a cysteine protease involved in atherogenesis (4-6). CTSS is synthesised in macrophages, smooth muscle cells, and endothelial cells and when released extracellularly it exerts elastolytic and collagenolytic activities leading to elastic lamina degradation, plaque rupture and necrotic core development $(7,8)$. Studies show that CTSS levels are increased in human and animal atheroma, in the abdominal aortic aneurysm (9) but not in non-atherosclerotic arteries $(4,10)$.

Since several theories are based on the fact that different risk factors promote atherosclerosis, the focus of this paper was on markers associated with CTSS in patients with AAA and AOD. Cystatin C (Cys C) is an endogenous inhibitor of cysteine peptidases also known as a marker for atherosclerosis (11). In vitro studies indicate that CTSS may have an impact on lipoproteins metabolism. Incubation of HDL3 (high-density lipoprotein), isolated by ultracentrifugation, with CTSS led to a rapid loss of pre -HDL and a reduced cholesterol efflux from macrophages p <0.001). Kada su pacijenti podeljeni prema HDL-C (sa HDL-C $\leq 0,90$ i HDL-C $>0,90 \mathrm{mmol} / \mathrm{L})$, vrednosti plazmatskog CTSS su se razlikovale među grupama $(31,27$ naspram 25,61 mg/L, respektivno, $\mathrm{p}<0,001)$.

Zaključak: Ovi rezultati pružaju prvi dokaz da je CTSS negativno povezan sa HDL-C i bilirubinom kod pacijenata sa AAA. Pretpostavka je da se na osnovu razlike u asocijaciji CTSS-a i drugih markera ateroskleroze može utvrditi da li će ateroskleroza aorte dovesti do dilatacije ili stenoze.

Ključne reči: aneurizma abdominalne aorte, katepsin $\mathrm{S}$, cistatin C, HDL-C

(12). Today, antioxidative and anti-inflammatory vasoprotective effects of $\mathrm{HDL}$ are well known (1315). In addition to this, the serum total bilirubin concentration is inversely associated with a risk in cardiovascular disease $(16,17)$ because the total bilirubin is a strong antioxidant in the human body $(18,19)$.

We analysed the plasma CTSS and other markers of atherosclerosis in patients with AAA and $A O D$, aiming to identify the underlying pathogenic mechanisms of the disease development. Also, our study was designed to examine whether the level of CTSS was higher if the level of HDL-C was lower in the entire group of patients.

\section{Materials and Methods}

\section{Subjects and blood sampling}

33 patients with $A A A$ and 34 patients with $A O D$ were included in this study. The patients consecutively enrolled from the Department of Surgery, at the University Clinical Centre of the Republic of Srpska, Banja Luka, Bosnia and Herzegovina. The collection period for the samples was from May 2014 to July 2015. The diagnosis of AAA and AOD was set up by using abdominal ultrasound and magnetic resonance angiography and based on a detailed clinical examination. Including criteria for the study were patients with AAA and AOD who would be treated surgically and who would have an elective surgical program. Patients with AAA and AOD operated on as urgent surgical cases, and those with previous surgery as well as patients with aneurysms at other localisation were excluded from the study. Some of them received statins and ACE inhibitors (angiotensin II or receptor antagonist). The study was approved by the National Ethics Committee, and all patients consented to participate. Blood was collected from the antecubital vein at the time of the preparation for surgery. 


\section{Methods}

The combination of 2B4 MAb and 1E3 MAb (Krka, d.d., Ljubljana, Slovenia) was used to optimise sandwich ELISA. Both antibodies recognise mature and pro-forms of CTSS. Microtitre plates were coated with $10 \mu \mathrm{g} \mathrm{mL}-1$ of $2 \mathrm{~B} 4 \mathrm{MAb}$ in $0.01 \mathrm{~mol} / \mathrm{L}$ carbonate/bicarbonate buffer, $\mathrm{pH} 9.4$ at $4{ }^{\circ} \mathrm{C}$. After blocking (2\% BSA-PBS, $150 \mu \mathrm{L}$ well-1), the samples or CTSS standards were added $(100 \mu \mathrm{L}$ well-1). After $2 \mathrm{~h}$ of incubation, wells were washed and filled with $1 \mathrm{E} 3$ MAb conjugated with HRP. After further $2 \mathrm{~h}$ of incubation at $37{ }^{\circ} \mathrm{C} 200 \mu \mathrm{g}$ well-1 of peroxidase substrate 3,3,5,5-tetramethylbenzidine (TMB, Sigma) $0.012 \% \mathrm{H}_{2} \mathrm{O}_{2}$ was added. After 15 minutes, the reaction was stopped by adding $50 \mu \mathrm{L}$ of $2 \mathrm{~mol} / \mathrm{L}$ $\mathrm{H}_{2} \mathrm{SO}_{4}$. The amount of degraded substrate, as a measure of bound immune-complexed CTSS, was determined by absorbance at $450 \mathrm{~nm}$, and the concentration of CTSS calculated from the calibration curve (20). Samples were processed in the same run. Cys C, HDL-C, triglycerides (TG), low-density lipoprotein cholesterol (LDL-C), total bilirubin, Apo A-I, CRP and alpha-1 antitrypsin were determined by Cobas 6000 analyser (Roche, Germany), by reagents from Roche Diagnostics (Roche Diagnostics, Mannheim, Germany), according to the manufacturer's instructions. We calculated the apoA/HDL-C ratio as index negatively associated with AAA. Fibrinogen was determined by the Clauss method (Siemens Healthcare Diagnostics).

\section{Statistical analysis}

All calculations were performed using SPSS v. 20.0 (SPSS Inc. Chicago, IL, USA). Numerical data are shown as a mean \pm standard deviation for normally distributed variables and as a median and interquartile range for non-normally distributed variables. Categorical variables are presented as relative frequencies. Comparisons of the data were performed by the unpaired Student's t-test for normally distributed data, and the Mann-Whitney Utest was used to compare data with skewed distribution between groups with AAA and AOD. Analysis of categorical variables was performed using the Chisquare test. Relations between the variables were determined using the Spearman rank-order correlation test. Using univariate and multivariate logistic regression analysis, we examined the predictors of a low HDL-C level.

\section{Results}

Clinical characteristics of the patients have been summarised in Table I. The groups with AAA $(n=33)$, and AOD $(n=34)$ did not differ in atherosclerosis risk factors (age, gender, hypertension, smoking habits, the presence of diabetes) and therapy (statins, ACE inhibitors). The youngest person was 46 , and the oldest 82. The abdominal aortic diameter was 3.50 $\mathrm{cm}$ minimum and $7.60 \mathrm{~cm}$ maximum, median 5.35 $\mathrm{cm}$. The baseline laboratory parameters of our patients are shown in Table II. From all examined parameters only, the bilirubin level was significantly lower in patients with $A O D$ compared to patients with AAA. On the other hand, fibrinogen, CRP and alpha1 antitrypsin had higher levels in patients with AOD.

HDL-C positively correlated with the total bilirubin $(r=0.423, p=0.014)$ and apo A-I $(r=$ $0.799, p<0.001)$ while it was negatively associated with CTSS $(r=-0.289, p=0.018)$, and TG $(r=-497$, $\mathrm{p}<0.001)$ ). In addition, CTSS was positively associated with TG $(r=0.359, p=0.003)$ levels. We did not find an association between Cys $\mathrm{C}$ and other parameters.

In the patients with AAA, the plasma CTSS was negatively associated with HDL-C $(r=-0.377, p=$

Table I Clinical characteristics of patients with AAA and AOD.

\begin{tabular}{|l|c|c|c|}
\hline Parameter & $\begin{array}{c}\text { AAA } \\
\mathrm{n}=33\end{array}$ & $\begin{array}{c}\text { AOD } \\
\mathrm{n}=34\end{array}$ & $\mathrm{p}$ \\
\hline Age (years) & $67.45 \pm 9.44$ & $65.87 \pm 7.67$ & $\mathrm{NS}$ \\
\hline Gender (male) & $84.0 \%$ & $66.5 \%$ & $\mathrm{NS}$ \\
\hline ACE inhibitors & $51.51 \%$ & $34.37 \%$ & $\mathrm{NS}$ \\
\hline Statin & $9.0 \%$ & $9.3 \%$ & $\mathrm{NS}$ \\
\hline Hypertension & $72.72 \%$ & $68.75 \%$ & NS \\
\hline Diabetes & $12.12 \%$ & $15.62 \%$ & NS \\
\hline Smoking & $69.69 \%$ & $66.66 \%$ & \\
\hline
\end{tabular}

Continuous variables are presented as mean \pm standard deviation and are compared with the Student's t-test, whereas categorical variables are presented as relative frequencies and are compared with Chi-square test. Abbreviations: AAA, abdominal aortic aneurysm; ACE, angiotensin-converting enzyme; $\mathrm{p}$, level of significance; NS, not significant, $\mathrm{p}>0.05$. 
Table II Laboratory findings of patients with AAA and AOD.

\begin{tabular}{|l|c|c|c|}
\hline Parameter & $\begin{array}{c}\text { AAA } \\
\mathrm{n}=33\end{array}$ & $\begin{array}{c}\text { AOD } \\
\mathrm{n}=34\end{array}$ & $\mathrm{P}$ \\
\hline CTSS $(\mu \mathrm{g} / \mathrm{L})^{*}$ & $30.82 \pm 13.09$ & $29.86 \pm 11.70$ & 0.833 \\
\hline CysC (mg/L) & $0.93(0.76 / 1.13)$ & $0.91(0.74 / 1.50)$ & 0.618 \\
\hline HDL-C (mmol/L)* & $1.09 \pm 0.35$ & $1.02 \pm 0.31$ & 0.145 \\
\hline Apo A-I (g/L)* & $1.28 \pm 0.26$ & $1.17 \pm 0.29$ & 0.501 \\
\hline Apo A/HDL-C* & $1.23 \pm 0.26$ & $1.19 \pm 0.25$ & 0.689 \\
\hline TG (mmol/L) & $1.78(1.19 / 2.36)$ & $3.70(1.11 / 2.44)$ & 0.230 \\
\hline LDL-C (mmol/L) & $4.00(2.92 / 5.20)$ & $8.25(6.25 / 9.50)$ & $<0.001$ \\
\hline Total bilirubin ( $\mu \mathrm{mol} / \mathrm{L})$ & $11.30(8.20 / 13.70)$ & $4.45(4.02 / 5.75)$ & 0.002 \\
\hline Fibrinogen (g/L) & $3.90(3.10 / 4.30)$ & $8.45(3.22 / 58.77)$ & 0.051 \\
\hline CRP (mg/L) & $4.25(2.10 / 12.70)$ & $1.69(1.54 / 1.98)$ & 0.005 \\
\hline Alpha-1 antitrypsin $(\mathrm{g} / \mathrm{L})$ & $1.51(1.28 / 1.71)$ & & \\
\hline
\end{tabular}

The values are presented as medians and interquartile range $(\mathrm{Q} 1 / \mathrm{Q} 3)$ or mean \pm standard deviation. Mann-Whitney $\mathrm{U}$-test was used to compare data between groups, except in variable marked with*, where the Student s t-test was used.

Abbreviations: AAA, abdominal aortic aneurysm; AOD, aortoiliac occlusive disease; Apo A-I, apolipoprotein A; CTSS, cathepsin S; Cys C, cystatin C; CRP, C-reactive protein; HDL-C, high-density lipoprotein cholesterol; LDL-C, low-density lipoprotein cholesterol; P, level of significance; TG, triglycerides.

Table III Laboratory findings of patients with AAA and AOD when the patients were divided according to HDL-C.

\begin{tabular}{|l|c|c|c|}
\hline Parameter & $\begin{array}{c}\text { Patients with HDL-C } \leq 0.90 \\
\mathrm{mmol} / \mathrm{L}, \mathrm{n}=30\end{array}$ & $\begin{array}{c}\text { Patients with HDL-C }>0.90 \\
\mathrm{mmol} / \mathrm{L}, \mathrm{n}=37\end{array}$ & $\mathrm{P}$ \\
\hline CTSS $(\mu \mathrm{g} / \mathrm{L})$ & $31.27(26.84 / 38.33)$ & $25.61(19.28 / 30.30)$ & $<0.001$ \\
\hline Cys C $(\mathrm{g} / \mathrm{L})$ & $1.08(0.78 / 1.32)$ & $0.90(0.76 / 1.10)$ & $<0.501$ \\
\hline TG $(\mathrm{mmol} / \mathrm{L})$ & $2.17(1.80 / 2.80)$ & $1.30(1.10 / 1.90)$ & 0.291 \\
\hline LDL-C $(\mathrm{mmol} / \mathrm{L})$ & $3.70(2.80 / 4.44)$ & $3.80(2.90 / 5.20)$ & 0.070 \\
\hline Total bilirubin $(\mu \mathrm{mol} / \mathrm{L})$ & $8.20(6.60 / 11.45)$ & $10.00(7.90 / 13.58)$ & $<$ \\
\hline
\end{tabular}

The values are presented as medians and interquartile range (Q1/Q3). Mann-Whitney U-test was used to compare data between groups.

Abbreviations: AAA, abdominal aortic aneurysm; CTSS, cathepsin S; Cys C, cystatin C; HDL-C, high-density lipoprotein cholesterol; LDL-C, low-density lipoprotein cholesterol; $p$, level of significance; TG, triglycerides.

$0.034)$ and total bilirubin $(r=-0.500, p=0.003)$, while, unexpectedly, it was not correlated with Cys $C$ $(r=0.083, p=0.652)$ and AAA diameter size $(r=$ $0.140, p=0.469)$. In addition, HDL-C was positively correlated with the total bilirubin $(r=0.423, p=$ 0.014 ) while it was not correlated with AAA diameter size. In the patients with AOD, CTSS was positively associated with TG only $(r=0.597, p<0.001)$. Also, the CTSS was not correlated with Cys $C(r=-0.035$, $p=0.842$ ).
The patients were divided into two groups according to $\mathrm{HDL}-\mathrm{C}$, i.e. patients with $\mathrm{HDL}-\mathrm{C} \leq 0.90$ $\mathrm{mmol} / \mathrm{L}(\mathrm{n}=30)$, also known as high-risk values and patients with HDL-C $>0.90 \mathrm{mmol} / \mathrm{L}(\mathrm{n}=37)$. There was a difference between the two analysed groups according to the CTSS concentration (Table III). The CTSS was significantly lower in patients with higher HDL-C than in patients with a lower HDL-C concentration. 
Table IV Odds ratios for examined parameters impact on the low HDL-C level.

\begin{tabular}{|l|c|c|}
\hline & $\begin{array}{c}\text { Unadjusted } \\
\text { OR }(95 \% \mathrm{Cl})\end{array}$ & $\mathrm{p}$ \\
\hline TG $(\mathrm{mmol} / \mathrm{L})$ & $2.561(1.324-4.953)$ & 0.005 \\
\hline $\begin{array}{l}\text { LDL-cholesterol } \\
(\mathrm{mmol} / \mathrm{L})\end{array}$ & $0.824(0.540-1.258)$ & 0.824 \\
\hline $\begin{array}{l}\text { Total bilirubin } \\
(\mu \mathrm{mol} / \mathrm{L})\end{array}$ & $0.990(0.924-1.061)$ & 0.773 \\
\hline CTSS $(\mu \mathrm{g} / \mathrm{L})$ & $1.067(1.012-1.126)$ & 0.017 \\
\hline Cys C $(\mathrm{mg} / \mathrm{L})$ & $1.410(0.422-4.714)$ & 0.557 \\
\hline $\begin{array}{c}\text { Adjusted } \\
\text { OR (95\% Cl) }\end{array}$ & $\mathrm{p}$ \\
\hline CTSS $(\mu \mathrm{g} / \mathrm{L})$ & $1.051(0.997-1.107)$ & 0.065 \\
\hline TG $(\mathrm{mmol} / \mathrm{L})$ & $2.251(1.150-4.406)$ & 0.018 \\
\hline
\end{tabular}

Multivariate logistic regression analysis was used to examine the predictors of the low HDL-C level. Abbreviations: $\mathrm{Cl}$, confidence interval; CTSS, cathepsin S; Cys C, cystatin C; HDL-C, high-density lipoprotein cholesterol; LDL-C, lowdensity lipoprotein cholesterol; TG, triglycerides; OR, odds ratio; $p$, level of significance.

We performed binary logistic regression analysis to determine whether examined parameters had the potential to predict low HDL-C concentrations $(\leq 0.9$ $\mathrm{mmol} / \mathrm{L}$ ). Univariate analysis revealed that increased TG and CTSS were significant predictors of low HDLC (Table IV). Furthermore, we explored confounders that may alter the association between a low HDL-C and CTSS concentration. The results of multivariate logistic regression analysis (Table IV) showed a weak association between the change in CTSS and a low HDL-C concentration. The association of CTSS with HDL-C low levels was not independent of TG concentrations.

\section{Discussion}

Our understanding of the mechanisms of AAA formation is still incomplete, indicating the need for searching novel biomarkers with predictive ability. This study shows that there was no difference in the level of plasma CTSS between patients with AAA and patients with AOD. CTSS was one of the first cysteinyl cathepsins discovered in human AAA lesions (17). Its activities in degrading fibronectin, elastin, collagen and laminin suggest its involvement in AAA formation and progression $(21,22)$ strongly. Also, the patients with atherosclerotic stenosis had significantly higher serum levels of CTSS than patients without cardiovascular complications (15). Nevertheless, we have shown, for the first time, the negative correlation between the plasma CTSS level and HDL-C in AAA patients. Results studies by Spielmann et al. (23) provide the first evidence that CTSS sequence variations are associated with two human metabolic risk factors for cardiovascular diseases: plasma ApoA1 and HDL-C concentrations. Based on their findings, Spielmann et al. (23) suggested that specific variants of the CTSS gene may play a role in determining the Apo-A1 and HDL-C profiles and may thus influence reverse cholesterol transport. Additionally, CTSS can have a negative effect on reverse cholesterol transport by inducing the degradation of lipidpoor preB-HDL and Apo-A1 (12). Our study greatly supports the findings of the mentioned studies that CTSS may have a negative impact on HDL-C metabolism. Also, when we compare CTSS adjustment to HDL-C, the patients with HDL-C $\leq 0.90 \mathrm{mmol} / \mathrm{L}$ had significantly higher values of CTSS than patients with $\mathrm{HDL}-\mathrm{C}>0.90 \mathrm{mmol} / \mathrm{L}$. It is still unclear why some patients develop an aneurysm and some occlusive arterial disease, despite similarities underlying the development of $A A A$ and $A O D$, including increased CTSS and decreased HDL-cholesterol. A concomitant increase of the CTSS level and a decrease of HDL-C in plasma of patients may suggest a new mechanism of CTSS-mediated vascular diseases, as well as the possibility that the same risk factors promote both AAA and AOD via similar mechanisms, but additional factors are required for AAA induction. The close interrelation between the increasing of CTSS level and the decreasing of HDL-C in plasma in all patients definitively needs further clarification. This study will help in further understanding of the biochemical role of CTSS and HDL-C in vascular disease.

In addition, we found a negative correlation between the plasma CTSS level and bilirubin in the plasma of AAA patients. The reason for this may be the fact that the apoptotic cell death is caused by cellular depletion of bilirubin (24) and consequently increases CTSS in the plasma. Altogether, higher circulating levels of CTSS have shown to be associated with decreased antioxidative activity in AAA patients. This study indicates that the mechanisms formation of AAA and AOD are different because we did not find the same CTSS association with other parameters in observed groups. It is possible that differences in the association of the CTSS and other markers can determine whether atherosclerotic aorta will develop dilatation or stenosis.

We should say, that our study is contrary to the study of Lv et al. (25) where there was a positive correlation between the plasma CTSS and AAA diameter size. In our study, a loss of correlation of the plasma CTSS and AAA diameter size could be the result of an advanced stage of the disease in our patients.

Although Burillo et al. (26) recently found a significant difference in the concentration of HDL-C among these patients, our study did not confirm this data (Table II). Yet, it is interesting that we found a 
significant difference in the concentration of total bilirubin between patients with AAA and patients with $A O D$, i.e. the plasma total bilirubin concentration was lower in the plasma of patients with AOD then in AAA patients. Bilirubin is recognised as a potent antioxidant (18), and lower total bilirubin could mean higher oxidative stress. In the development of vascular disease, oxidative stress plays a critical role, and the subjects with elevated bilirubin levels had a diminished risk of atherosclerosis (17). The total bilirubin and HDL-C are strong antioxidants $(18,19)$, and our study shows a correlation between these two biochemical markers in patients with AAA, a similar correlation was shown in Oda's study (27).

Likewise, in our study, in the patients with AOD, the plasma CTSS concentration was significantly associated with TG, which is an independent atherosclerosis risk factor. This is very important information because a similar correlation was shown in stable angina patients (28). The exact mechanisms responsible for this remain unclear, but a close interrelation between the level of CTSS and atherogenic plasma TG opens new questions about the complex pathways of vascular diseases. Also, this group of patients had significantly higher markers of inflammation, respectively, which are well known to be underlying factors for atherosclerosis.

The often-described background mechanism linking Cys $C$ with atherogenesis is that it is a potent endogenous inhibitor of CTSS $(11,29)$. In this respect, we expected the association of decreased Cys C concentrations with an increased CTSS. Contrary to our expectation, in our study, the plasma Cys C concentration was not associated with the plasma CTSS, and it did not correlate with AAA diameter size. Lindholt et al. (30) showed that the Cys C deficiency is associated with the progression of small abdominal aortic aneurysms, but our results did not support this claim, perhaps because we examined the progressive phase of the AAA. However, it is difficult to clarify what influenced the loss of this control mechanism between proteinase and its inhibitor, but we could assume that this disbalance played a significant role in the development of these diseases.
This study has limitations, i.e. it includes a small sample size and some patients taking the statin and antihypertensive medications. Nowadays it is not known whether conventional therapy may influence the CTSS concentration in atherogenesis. The scarce studies of statins and CTSS are contrary; one indicated that the statin treatment did not change CTSS activity in the wall of the abdominal aortic aneurysm (31), another indicated that simvastatin decreased CTSS in CVD $(28,32)$. ACE inhibitors or angiotensin II receptor antagonist also decrease CTSS mRNA and/or activity (33). Undoubtedly, further studies need to explain the exact drug action mechanism in the CTSS.

\section{Conclusion}

These results provide the first evidence that plasma CTSS is associated with HDL-C and bilirubin in the patients with AAA. Also, the patients with HDL$\mathrm{C} \leq 0.90 \mathrm{mmol} / \mathrm{L}$ had significantly higher values of CTSS than patients with HDL-C $>0.90 \mathrm{mmol} / \mathrm{L}$. Likewise, in our study, in the patients with $A O D$, the plasma CTSS concentration was significantly associated with TG. It is still unclear why some patients develop an aneurysm and some occlusive arterial disease, regardless of similarities underlying the development of $A A A$ and $A O D$, including increased CTSS and decreased HDL-cholesterol. It is possible that differences in the association of the CTSS and other markers of atherosclerosis may determine whether atherosclerotic aorta will develop into a dilatative or stenotic disease.

Acknowledgements. We gratefully acknowledge the subjects who participated in our study for helping us with sample processing.

\section{Conflict of interest statement}

The authors stated that they have no conflicts of interest regarding the publication of this article. 


\section{References}

1. Golledge J, Norman P. Atherosclerosis and abdominal aortic aneurysm: cause, response or common risk factors? Arterioscler Thromb Vasc Biol 2010; 30: 1075-7.

2. Clair DG, Beach JM. Strategies for managing aortoiliac occlusions: access, treatment and outcomes. Expert Rev Cardiovasc Ther 2015;13: 551-63.

3. Peshkova I. O, Schaefer G, Koltsova E. K. Atherosclerosis and aortic aneurysm - is inflammation a common denominator? FEBS J 2016; 283: 1636-52.

4. Wilkinson RD, Williams R, Scott CJ, Burden RE. Cathepsin S: therapeutic, diagnostic, and prognostic potential. Biol Chem 2015; 396(8): 867-82.

5. Figueiredo JL, Aikawa M, Zheng C, Aaron J, Lax L, Libby $P$, et al. Selective cathepsin $S$ inhibition attenuates atherosclerosis in apolipoprotein E-deficient mice with chronic renal disease. Am J Pathol 2015; 185: 1156-66.

6. Liu J, Sukhova GK, Sun JS, Xu WH, Libby P, Shi GP. Lysosomal cysteine proteases in atherosclerosis. Arterioscler Thromb Vasc Biol 2004; 24: 359-66.

7. Lutgens SP, Cleutjens KB, Daemen MJ, Heeneman S. Cathepsin cysteine proteases in cardiovascular disease. FASEB J 2007; 21: 3029-41.

8. Sukhova GK, Shi GP, Simon DI, Chapman HA, Libby P. Expression of the elastolytic cathepsins $\mathrm{S}$ and $\mathrm{K}$ in human atheroma and regulation of their production in smooth muscle cells. J Clin Invest 1998; 102: 576-83.

9. Qin Y, Yang Y, Liu R, Cao X, Liu O, Liu J, et al. Combined Cathepsin $\mathrm{S}$ and hs-CRP predicting inflammation of abdominal aortic aneurysm. Clin Biochem 2013; 46: 1026-9.

10. Jormsjö S, Wuttge D, Sirsjö A, Whatling C, Hamsten A, Stemme $S$, et al. Differential expression of cysteine and aspartic proteases during progression of atherosclerosis in apolipoprotein E-deficient mice. Am J Pathol 2002; 161: 939-45.

11. Marković $D$, Jevtović-Stoimenov $R$, Ćosić $V$, Stošić $B$, Dinić V, Marković-Živković B, Janković JR. Clinical utility of survivin (birc5), novel cardiac biomarker as a prognostic tool compared to high-sensitivity c-reactive protein, heart-type fatty acid binding protein and revised Lee score in elderly patients scheduled for major Noncardiac surgery: a prospective pilot study. J Med Biochem 2018; 37: 110-20.

12. Lindstedt $L$, Lee $M$, Öörni $K$, Brömme D, Kovanen PT. Cathepsins F and S block HDL3-induced cholesterol efflux from macrophage foam cells. Biochem Biophys Res Commun 2003; 312: 1019-24.

13. Rye K-A. High density lipoprotein structure, function, and metabolism: a new Thematic Series. J Lipid Res 2013; 54: 2031-3.

14. Kontush A and Lhomme M. Lipidomics of Plasma HighDensity Lipoprotein: Insights into Anti-Atherogenic Function. J Glycomics Lipidomics 2015; 5: 3-6.

15. Karathanasis SK, Freeman LA, Gordon SM, Remaley AT. The changing face of HDL and the best way to measure it. Clin Chem 2017; 63: 196-210.
16. Djoussé L, Levy D, Cupples LA, Evans JC, D'Agostino RB, Ellison RC. Total serum bilirubin and risk of cardiovascular disease in the Framingham offspring study. Am j Cardiol 2001; 87: 1196-200.

17. Novotný L, Vítek L. Inverse relationship between serum bilirubin and atherosclerosis in men: a meta-analysis of published studies. Exp Biol Med (Maywood) 2003; 228: 568-71.

18. Vitek $L$, Jirsa $M$, Brodanová $M$, Kalab M, Marecek Z, Danzig $V$, et al. Gilbert syndrome and ischemic heart disease: a protective effect of elevated bilirubin levels. Atherosclerosis 2002; 160: 449-56.

19. Delbosc S, Diallo D, Dejouvencel T, Lamiral Z, Louedec L, Martin-Ventura JL, et al. Impaired high-density lipoprotein anti-oxidant capacity in human abdominal aortic aneurysm. Cardiovasc Res 2013; 100: 307-15.

20. Kos J, Sekirnik A, Kopitar G, Cimerman N, Kayser K, Stremmer $A$, et al. Cathepsin $S$ in tumours, regional lymph nodes and sera of patients with lung cancer: relation to prognosis. Brit J Cancer 2001; 85: 1193200.

21. Qin $Y$, Cao X, Guo J, Zhang Y, Pan L, Zhang H, et al. Deficiency of cathepsin $S$ attenuates angiotensin II-induced abdominal aortic aneurysm formation in apolipoprotein E-deficient mice apolipoprotein E-deficient mice. Cardiovasc Res 2012; 96: 401-10.

22. Taleb S, Cancello R, Clément K, Lacasa D. Cathepsin S promotes human preadipocyte differentiation: possible involvement of fibronectin degradation. Endocrinology 2006; 147: 4950-9.

23. Spielmann N, Mutch DM, Rousseau F, Tores F, Hager J, Bertrais $\mathrm{S}$, et al. Cathepsin $\mathrm{S}$ genotypes are associated with Apo-A1 and HDL-cholesterol in lean and obese French populations. Clin Genet 2008; 74: 155-63.

24. Baranano DE, Rao M, Ferris CD, Snyder SH. Biliverdin reductase: a major physiologic cytoprotectant. Proc Natl Acad Sci U S A 2002; 99: 16093-8.

25. Lv BJ, Lindholt JS, Cheng X, Wang J, Shi GP. Plasma cathepsin $S$ and cystatin $C$ levels and risk of Abdominal Aortic Aneurysm: a randomized population-based study. PLoS 2012; 7: e41813.

26. Burillo E, Lindholt JS, Molina-Sanchez P, Jorge I, MartinezPinna R, Blanco-Colio LM, et al. ApoA-I/HDL-C levels are inversely associated with abdominal aortic aneurysm progression. Thromb Haemost 2015; 113: 1335-46.

27. Oda E. Cross-sectional and longitudinal associations between serum bilirubin and dyslipidemia in a health screening population. Atherosclerosis 2015; 239: 31-7.

28. Mirjanic-Azaric B, Vekic J, Zeljkovic A, Jelic-Ivanovic Z, Djeric M, Milivojac T, et al. Interrelated cathepsin Slowering and LDL subclass profile improvements induced by atorvastatin in the plasma of stable angina patients. J Atheroscler Thromb 2014; 21: 868-77.

29. Telo S, Kuluöztürk M, Deveci F, Kırkıl G, Öner Ö, Kaman D. Serum cystatin C levels in COPD: potential diagnostic value and relation between respiratory functions. J Med Biohem 2018; 37: 434-40. 
30. Lindholt JS, Erlandsen EJ, Henneberg EW. Cystatin C deficiency is associated with the progression of small abdominal aortic aneurysms. Br J Surg 2001; 88: 14725.

31. Abisi S, Burnand KG, Waltham M, Humphries J, Taylor $\mathrm{PR}$, Smith A. Cysteine protease activity in the wall of abdominal aortic aneurysms. J Vasc Surg 2007; 46: 1260-6.

32. Qin YW, Ye P, He JQ, Sheng L, Wang LY, Du J. Simvastatin inhibited cardiac hypertrophy and fibrosis in apolipoprotein E-deficient mice fed a »Western-style diet" by increasing PPAR and expression and reducing TC, MMP-9, and Cat S levels. Acta Pharmacol Sin 2010; 31: 1350-8.

33. Cheng XW, Murohara T, Kuzuya M, Izawa $H$, Sasaki T, Obata K, et al. Superoxide-dependent cathepsin activation is associated with hypertensive myocardial remodelling and represents a target for angiotensin II type 1 receptor blocker treatment. Am J Pathol 2008; 173: 358-69.

Received: September 25, 2018

Accepted: October 16, 2018 